\title{
AÇÃO RESCISÓRIA E AÇÃO DECLARATÓRIA DE INEXISTÊNCIA (QUERELA NULLITATIS INSANABILIS): APLICAÇÃO DO PRINCÍPIO DA FUNGIBILIDADE
}

\section{Eduardo Peruffo e Silva ${ }^{1}$}

Resumo: O presente artigo tem por objetivo diferenciar, de forma breve, as ações autônomas de impugnação de decisões judiciais, com foco na Ação Rescisória e na Ação Declaratória de Inexistência, bem como demonstrar os requisitos da aplicação do princípio da fungibilidade e mais, visa a analisar a possibilidade de aplicação do referido princípio quando se tratar da Ação Rescisória e Querela nullitatis, com embasamento doutrinário e jurisprudencial.

Palavras-Chave: Ação rescisória. Ação declaratória de inexistência. Querela nullitatis insanabilis. Fungibilidade. Instrumentalidade das formas.

\section{AÇÕES AUTÔNOMAS DE IMPUGNAÇÃO}

A categoria das ações autônomas visa, juntamente com os recursos, a impugnação de decisões judiciais que empreendem em prejuízo a alguma das partes. Tem sido de grande utilidade atualmente, em especial quando verificadas as reformas legislativas que tem limitado o acesso recursal das partes (por exemplo, a irrecorribilidade de decisões interlocutórias no âmbito dos Juizados Especiais, o que leva ao manejo de Mandado de Segurança).

1 Graduado em Direito pela Universidade de Cuiabá. Aluno da Escola Superior da Magistratura do Estado de Santa Catarina (ESMESC). Juiz Leigo no Juizado Especial Cível Norte da Ilha (Trindade). Advogado. E-mail: peruffo_peruffo@hotmail.com 
Sobre o tema, trata MEDINA e TERESA WAMBIER:

Além dos recursos, as decisões judicias podem ser impugnadas por ações autônomas, que se caracterizam por formar relação processual distinta daquela em que foi proferida a decisão impugnada ${ }^{2}$.

Posto isto, nos empreende delimitar alguns aspectos acerca das ações em estudo.

\subsection{Ação rescisória}

A Ação Rescisória no Direito brasileiro, prevista nos arts. 485 a 495 do CPC presta, inicialmente, a impugnar decisões judiciais acobertadas pelo manto da coisa julgada. Sobre o tema, leciona FREDIE DIDIER JR.:

A ação rescisória ostenta a natureza de ação autônoma de impugnação, voltando-se contra a decisão de mérito transitada em julgado, quando presente pelo menos umas das hipóteses previstas no art. 485 do CPC. A coisa julgada, no direito brasileiro, pode ser desconstituída, basicamente, por três meios: a ação rescisória (o comum), a querela nullitatis e a impugnação de sentença fundada no $\S 1^{\circ}$ do art. 475-L e no parágrafo único do art. 741 do $\mathrm{CPC}^{3}$.

Já decidiu inclusive, o STJ, que não se admite a presente ação contra decisão que não se pronunciou acerca do mérito da questão, senão vejamos (STJ, REsp n. 1.000.445/PR. Rel. Min. Eliana Calmon):

PROCESSUAL CIVIL - AÇÃO RESCISÓRIA: DESCABIMENTO - ART. 485 DO CPC ACÓRDÃO QUE AFASTOU A EXISTÊNCIA DE ERRO MATERIAL - MC 13.379/PR PREJU.

2 MEDINA. José Miguel Garcia. Recursos e Ações Autônomas de Impugnação. 2 ed. São Paulo: RT, 2011. P. 269.

3 DIDIER JR. Fredie. Curso de Direito Processual Civil: meios de impugnação às decisões judiciais e processo nos tribunais. 3 ed. Salvador: JusPodivm, 2007. P.293. 
DICADA. 1. Acórdão recorrido limitou-se tão-somente a concluir que inexistia erro material e, portanto, o julgador não poderia ter, de ofício, efetuado a revisão do montante executado. 2. Descabe a ação rescisória para desconstituir acórdão que não adentrou no mérito. Inteligência do art. 485 do CPC. 3. MC 13.379/PR prejudicada por perda de objeto. 4 . Recurso especial não provido.

Ainda, importante decisão do c. STJ proferida no REsp n. 474.002/RS (Rel. Min. Luis Felipe Salomão):

Somente os acórdãos que enfrentam o mérito da questão são sujeitos à rescisão, na forma do art. 485, caput, do CPC. Nesse caso, o pronunciamento do órgão ad quem substitui a sentença contra a qual foi manejada o recurso. Porém, tal não ocorre quando o tribunal competente para o julgamento do apelo, dele não conhece. Nesse caso, não havendo substituição da sentença hostilizada, somente essa poderá dá ensejo ao ajuizamento de ação rescisória, mas não o acórdão.

Sobre a conceituação de ação rescisória, leciona MEDINA e TERESA WAMBIER:

O meio criado pela Lei como adequado e eficaz para se impugnar decisões judicias sobre as quais pese a autoridade da coisa julgada é a ação rescisória, que é procedimento especial e, via de regra, comporta três juízos: $1^{\circ}$ ) o de admissibilidade, em que se verifica se se encontram presentes os requisitos de admissibilidade de tal ação; $2^{\circ}$ ) juízo de mérito, que comporta, sempre, o de anulação (juízo rescindens); e, em regra, também o $3^{\circ}$ ) de rejulgamento rescissorium $)^{4}$.

Passada esta fase de classificação, há de se verificar, rapidamente, o objeto da respectiva ação. Como já exposto ante-

4 MEDINA. Op. Cit. P. 282. 
riormente, a rescisória tem por escopo desfazer a coisa julgada material. Assim ensina DIDIER JR:

A ação rescisória serve ao desfazimento da coisa julgada material, quer por motivos de invalidade (art. 485, II e IV, p.ex.), quer por motivos de injustiça (art. 485, VI e IX, p.ex). Não se deve, pois, estabelecer uma relação necessária entre os defeitos processuais e a ação rescisória, pois esta tem espectro mais amplo.

Trata-se em verdade de uma ação constitutiva negativa ou desconstitutiva, porquanto visa ao desfazimento de coisa julgada anteriormente formada em outro processo. Como toda ação, a rescisória deve preencher as condições da ação e o procedimento deve observar os pressupostos processuais 5 .

Pode-se perceber, de início, que a ação rescisória não é recurso, mas sim ação autônoma. Sua natureza jurídica própria o é pela formação de nova relação jurídico-processual, dever de obediência às condições da ação, e, principalmente, por não incidir nas hipóteses taxativas dos recursos previstos na lei processual.

Quanto ao seu cabimento, há de se ressaltar que o rol que prevê suas hipóteses é taxativo (art. 485 do CPC). Inexiste, ainda, possibilidade de ampliação do conteúdo por interpretação analógica, como comenta DIDIER JR.:

Não se admite ação rescisória, sem que se alegue ou se demonstre a ocorrência de uma das hipóteses capituladas no art. 485 do CPC. O elenco de hipóteses do referido art. 485 do CPC é taxativo. Em outras palavras, 'as hipóteses que ensejam a rescisão da sentença estão arroladas em numerus clausus na norma ora comentada. Este rol taxativo não admite ampliação por interpretação analógica ou extensiva'. Vale dizer que 'o rol do art. 485 é taxativo. Não comporta interpretação ampliativa ou analógica'. Esse entendimento, tranquilo em

5 DIDIER Jr. Op. Cit. p. 294. 
doutrina e jurisprudência, afina-se à proteção constitucional da coisa julgada (art. $\left.5^{\circ}, \mathrm{XXXVI}\right)^{6}$.

Contudo, entendemos de maneira diversa. Há de se sopesar as hipóteses de estrita legalidade do rol na lei processual (inclusive na incidência do prazo de 02 anos) com as inovações e as mutações sociais trazidas ao Direito. Filiamonos à corrente adotada por MEDINA e TERESA WAMBIER, que entendem possível rescisória por exame de DNA posterior ao prazo decadencial, conforme se coloca:

Temos sugerido, em outros estudos, sejam as hipóteses de cabimento da ação rescisória, previstas no art. 485 do CPC, interpretadas em consonância com outros princípios que regem a temática relativa às técnicas de criação, estabilidade e revisão das decisões judiciais. Essa postura que temos em face do Direito é que nos autoriza sustentar que, ainda que não haja alteração legislativa no art. 485 do CPC, é possível, p. ex., o ajuizamento de ação rescisória com fundamento em exame de DNA obtido após ultrapassado o prazo de 2 anos do trânsito em julgado da sentença proferida em ação de investigação de paternidade, inserindo-se na hipótese, a fortiori, no inciso VII do art. 485 do CPC

Tem-se, na verdade, que os dispositivos legais - e assim também o art. 485 do CPC - não podem ser interpretados isoladamente, mas em consonância com os princípios constitucionais que dizem respeito à atuação jurisdicional. ${ }^{7}$

Sobre o tema, já existe posicionamento do STJ nesse sentido (REsp 300.084/GO, rel. Min. Humberto Gomes de Barros):

AÇÃO RESCISÓRIA - INVESTIGAÇÃO DE PATERNIDADE - EXAME DE DNA APÓS O TRÂNSITO EM JULGADO - POSSIBILIDADE FLEXIBILIZAÇÃO DO CONCEITO DE DOCU.

6 DIDIER Jr. Op. Cit. p. 294

7 MEDINA. Op. Cit. p. 287 
MENTO NOVO NESSES CASOS. SOLUÇÃO PRÓ VERDADEIRO "STATUS PATER".

- O laudo do exame de DNA, mesmo posterior ao exercício da ação de investigação de paternidade, considera-se "documento novo" para aparelhar ação rescisória (CPC, art. 485, VII). É que tal exame revela prova já existente, mas desconhecida até então. A prova do parentesco existe no interior da célula. Sua obtenção é que apenas se tornou possível quando a evolução científica concebeu o exame intracitológico.

Outro tema de relevo é quanto à competência para julgamento da ação. A ação rescisória constitui demanda de competência originária dos tribunais, não se admitindo seu ajuizamento perante o primeiro grau, vez que cabe ao próprio tribunal a rescisão de seus julgados.

Interessante questionamento se faz quando tratamos de sentença de mérito que transita em julgado sem apelação. Sobre o tema, DIDIER JR:

Proferida uma sentença de mérito, e não havendo recurso de apelação, é a própria sentença que transita em julgado, devendo a ação rescisória ser intentada junto ao tribunal ao qual o juízo está vinculado. Caso haja apelação, mas esta não seja conhecida, não é o acórdão do tribunal que transita em julgado. É que, não conhecido o recurso, não se opera o efeito substitutivo previsto no art. 512 do CPC, restando incólume a sentença de mérito proferida no juízo de primeira instância. Nesse caso é a própria sentença que transita em julgado ${ }^{8}$.

\subsection{Ação declaratória de inexistência (Querela nullitatis insanabilis)}

Interessante construção da ação declaratória de inexistência que é usada quando se traz à baila sentença juridica8 DIDIER JR. Op. Cit. p. 305. 
mente inexistente. Sobre o tema leciona MEDINA e TERESA WAMBIER:

Em se tratando de sentença juridicamente inexistente (p. ex., proferida sem a citação do réu, ou quando julga procedente pedido juridicamente impossível), o meio adequado para retirar definitivamente do mundo jurídico as sentenças inexistentes é o da ação declaratória, que, no caso, é imprescritível9.

Quanto ao tema sentenças juridicamente inexistentes, assim entende o Superior Tribunal de Justiça, em julgamento didático (REsp 622.405/SP. Rel. Min. Denise Arruda):

Segundo a teoria da relativização da coisa julgada, haverá situações em que a própria sentença, por conter vícios insanáveis, será considerada inexistente juridicamente. Se a sentença sequer existe no mundo jurídico, não poderá ser reconhecida como tal, e, por esse motivo, nunca transitará em julgado.

Conforme disposto pelo STJ, a ideia do não trânsito em julgado leva-nos a trazer alguns conceitos sobre coisa julgada. Sobre o tema, bem acerta NELSON NERY JÚNIOR, que faz um paralelo entre coisa julgada e segurança jurídica:

Coisa julgada material (auctoritas rei iudicatae) é a qualidade que torna imutável e indiscutível o comando que emerge da parte dispositiva da sentença de mérito não mais sujeita ao recurso ordinário ou extraordinário (CPC 467; LICC $6^{\circ}$ §3), nem à remessa necessária do CPC 475. Somente ocorre se e quando a sentença de mérito tiver sido alcançada pela preclusão, isto é, a coisa julgada formal é pressuposto para que ocorra a coisa julgada material, mas não o contrário. A coisa julgada material é um efeito especial da sentença transitada formalmente em julgado. A segurança jurídica, trazida pela coisa julgada material, é mani-

9 MEDINA. Op. Cit. P. 275. 
festação do estado democrático de direito (CF $1^{\circ}$ caput). Entre o justo absoluto, utópico, e o justo possível, realizável, o sistema constitucional brasileiro, a exemplo do que ocorre na maioria dos sistemas ocidentais, optou pelo segundo (justo possível), que é consubstanciado na segurança jurídica da coisa julgada material. Descumprir-se a coisa julgada é negar o próprio estado democrático de direito, fundamento da república brasileira. A lei não pode modificar a coisa julgada material (CF 5० XXXVI); a CF não pode ser modificada para alterar-se a coisa julgada material (CF $1^{\circ}$ caput e 60 $\S 4$ ); o juiz não pode alterar a coisa julgada (CPC 467 e 471). Somente a lide (pretensão, pedido, mérito) é acobertada pela coisa julgada material, que a torna imutável e indiscutível, tanto no processo em que foi proferida a sentença, quanto em processo futuro. Somente as sentenças de mérito, proferidas com fundamento no CPC 269, são acobertadas pela autoridade da coisa julgada; as de extinção do processo sem julgamento de mérito (CPC 267) são atingidas apenas pela preclusão (coisa julgada formal). A coisa julgada material é instrumento de pacificação social ${ }^{10}$.

Sobre a coisa julgada e sua ausência, ensina MEDINA e TERESA WAMBIER:

A coisa julgada, enquanto fenômeno decorrente de princípio ligado ao Estado Democrático de Direito, convive com outros princípios fundamentais igualmente pertinentes. Ademais, como todos os atos oriundos do Estado, também a coisa julgada se formará se presentes pressupostos legalmente estabelecidos. Ausentes estes, de duas, uma: (a) ou a decisão não ficará acobertada pela coisa julgada, ou (b) embora suscetível de ser atingida pela coisa julgada, a decisão poderá, ainda assim, ser revista pelo próprio Estado, desde que presentes motivos

10 NERY JUNIOR, Nelson. Princípios do processo na Constituição Federal: processo civil, penal e adminstrativo. 10 ed. São Paulo: RT, 2010. P. 52. 
preestabelecidos na norma jurídica, adequadamente interpretada ${ }^{11}$.

Verifica-se, então, brevemente, a distinção entre a ação rescisória, que se presta a impugnar decisão judicial com transito em julgado, e ação declaratória de inexistência, que busca declarar ausência no mundo jurídico de decisão que nem mesmo força tem para transitar em julgado, não fazendo, assim, coisa julgada.

Contudo, antes de adentrarmos especificamente na ação declaratória de inexistência, cumpre tecermos breves comentários quanto ao tema sentença e seus aspectos necessários para que esta surta efeitos no mundo jurídico.

Explica TERESA ARRUDA ALVIM WAMBIER, que defendeu em sua tese de mestrado "As nulidades do processo e da sentença”:

Como todo ato jurídico, a sentença comporta exame sob tríplice aspecto: a existência jurídica em si mesma, a validade e a eficácia. A sentença existe desde que contenha os elementos essenciais que a configurem como tal, que contenha um dispositivo, seja dada por um juiz, etc., e desde que tenha sido proferida dentro de um processo juridicamente existente ${ }^{12}$.

Em sua doutrina, TERESA WAMBIER traz importante julgado do TACivSP (Ap. Sum. 143.015, rel. Roberto Grassi), em que se exemplifica o que é uma sentença inexistente:

A bem dizer-se, inexiste sentença. O magistrado limitou-se a preencher os espaços em branco de duas páginas mimeografadas, em que, à guisa de relatório, faz simples remissão ao suceder do encadeamento procedimental e respectivo numero de folhas. Assim, não se tem em mãos um histórico

11 WAMBIER, Teresa Arruda Alvim e MEDINA, José Miguel Garcia. O Dogma da Coisa Julgada: Hipóteses de Relativização. São Paulo: Editora Revista dos Tribunais, 2003, pág. 25

12 WAMBIER, Teresa Arruda Alvim. Nulidades do processo e da sentença. 6 ed. São Paulo: RT, 2007. P. 460. 
demonstrativo da tese da postulação, a que se contrapõe a antítese contestatória; deparamo-nos, em verdade, com nada mais que um índice numérico de folhas dos autos, em que se especifica a topologia do que deve, à força, ser produzido e não do que produzido foi em toda sua extensão... mesmo porque, para o 'anormal' incidente, inexiste 'vazio', 'branco' a preencher. (...)

A fundamentação - e só identificada porque foi como tal 'batizada' na decisão - assim vem esboçada: a conclusão do perito do juízo constitui, na hipótese, fundamento de decidir. Ora, tal fundamentação é a mais completa confissão de... ausência de confissão.

Desconstitui-se, pois, o feito, a partir de fls., inclusive, e com a recomendação de que os impressos sentenciais remanescentes seja, de futuro, usados em seu verso como papel em rascunho ${ }^{13}$.

Assim, pode-se perceber que, conforme declarado pelo relator, a sentença inexiste, e como explanado por TERESA WAMBIER, a sentença tem, como todo ato jurídico, que se submeter os elementos formadores da escada ponteana. Não o cumprindo, o ato jurídico nem mesmo existe devendo ser "usados em seu verso como papel em rascunho".

Portanto, verifica-se que a sentença inexistente, não tem o condão de transitar em julgado, e, por via reflexa, também não pode fazer coisa julgada. Importante lição traz NERY JR:

A sentença de mérito transitada em julgado faz coisa julgada material e, portanto, só pode deixar de produzir efeitos depois de rescindida por ação rescisória, quando estiver viviada por falta de pressuposto processual de validade ou por falta de condição da ação. $\mathrm{O}$ único dos requisitos do processo e da ação que enseja a inexistência da sentença e, por consequência, a inexistência da coisa julgada, dispensando o ajuizamento de ação

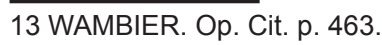


rescisória, é a sentença proferia do processo no qual falte pressuposto processual de existência. (...)

Para que a sentença de mérito, proferida pelo juiz no processo civil, adquira autoridade da coisa julgada (coisa julgada material), é necessário que estejam presentes os pressupostos processuais de existência: jurisdição do juiz, petição inicial, capacidade postulatória (somente para o autor) e citação do réu (quando necessária). Presentes os pressupostos de existência da relação jurídica processual, o processo existe e, consequentemente, a sentença que nele vier a ser proferida, se de mérito, será acobertada pela auctoritas rei iudicatae, tornando-se imutável, indiscutível e inatingível. Caso falte um dos pressupostos processuais de existência, o processo inexiste e a sentença que nele vier a ser proferida será, igualmente, inexistente: não terá força de coisa julgada e por isso prescinde de rescisão porque não produz nenhum efeito ${ }^{14}$.

É nessa seara que entra em cena a querela nullitatis.

Exemplificando-se, acerta MEDINA e TERESA WAMBIER:

O exemplo mais comum, como se lembrou, de sentença juridicamente inexistente é o da sentença de procedência proferida sem que tenha sido citado o réu. Não se confundem sentenças juridicamente inexistentes e sentenças nulas. Estas, embora viciadas, transitam em julgado podendo, se for o caso, ser atacadas através de ação rescisória ${ }^{15}$.

Sobre tal distinção, é a jurisprudência do Superior Tribunal de Justiça (REsp 62.853/GO, rel. min. Fernando Gonçalves):

PROCESSUAL CIVIL. USUCAPIÃO. CITAÇÃO. CONFRONTANTE. AUTOR. RESCISÓRIA. DESCABIMENTO.

14 NERY JUNIOR. Op. Cit. p. 55 15 MEDINA. Op. Cit. p. 276. 
1 - Se o móvel da ação rescisória é a falta de citação de confrontante (ora autor), em ação de usucapião, a hipótese é de ação anulatória (querella nulitatis) e não de pedido rescisório, porquanto falta a este último pressuposto lógico, vale dizer, sentença com trânsito em julgado em relação a ele. Precedentes deste STJ.

2 - Recurso conhecido em parte e, nesta extensão, provido para decretar a extinção do processo rescisório sem julgamento de mérito (art. 267, VI do CPC).

A jurisprudência catarinense segue neste mesmo sentido:

PROCESSUAL CIVIL - QUERELA NULLITATIS - AUSÊNCIA DE CITAÇÃO - NULIDADE "A doutrina e a jurisprudência são unânimes em afirmar que a ausência de citação ou a citação inválida configuram nulidade absoluta insanável por ausência de pressuposto de existência da relação processual, o que possibilita a declaração de sua inexistência por meio da ação querela nullitatis" (STJ, Resp 1015133/MT, Rel. Min. Eliana Calmon, rel. p/ acórdão Ministro Castro Meira, julgado em 02/03/2010). (TJSC, Apelação Cível n. 2012.016568-8, de Catanduvas, rel. Des. Luiz Cézar Medeiros, j. 09-07-2013).

A corte catarinense, inclusive, tem entendimento sumulado sobre o tema, conforme se extrai do enunciado da súmula 07 do TJSC: A ação declaratória é o meio processual hábil para se obter declaração de nulidade no processo que tiver corrido à revelia do réu por ausência de citação ou por citação nulamente feita.

Cumpre, ainda, verificar alguns pontos específicos sobre a querela. Quanto ao prazo, esta se distingue plenamente da ação rescisória. Enquanto esta deve ser proposta no prazo decadencial de até dois anos após o transito em julgado da decisão (art. 495), aquela não tem prazo para ser interposta.

Essa ausência de prazo se justifica por ser um ato juridicamente inexistente, e assim o sendo, não produz nenhum efeito, 
nem mesmo o de dar início à contagem de qualquer prazo. Sobre o tema disserta TERESA WAMBIER:

Acertada é a opinião segundo a qual o meio adequado para retirar definitivamente do mundo jurídico as sentenças inexistentes é o da ação declaratória, que, no caso, é imprescritível. Diz-se, quase unanimamente na doutrina, que as ações declaratórias são imprescritíveis.

Isso se justifica porque a finalidade das ações declaratórias é a de suprimir, do universo jurídico, uma determinada incerteza jurídica. Segue-se daí que, enquanto existir ou subexistir, e precisamente porque está presente uma determinada incerteza jurídica, não há lugar para a prescrição da ação declaratória, cujo objetivo é precipuamente o de pôr fim a essa incerteza. ${ }^{16}$

Além, a competência para julgamento de tal ação é do juízo que proferiu a própria decisão. Com isso concordamos com DIDIER JR.:A competência para a querela nullitatis é do juizo que proferiu a decisão nula, seja o juizo monocrático, seja o tribunal, nos casos em que a decisão foi proferida em processo de sua competência de origem. ${ }^{17}$

\section{PRINCÍPIO DA FUNGIBILIDADE E SUA APLICAÇÃO NAS AÇÕES RESCISÓRIA E DECLARATÓRIA DE INEXISTÊNCIA (QUERELA NULLITATIS INSANABILIS)}

Inicialmente, sobre o princípio da fungibilidade e da instrumentalidade das formas, leciona TERESA WAMBIER, com maestria:

A fungibilidade de meios é um tema que nos vem preocupando acentuadamente nos últimos anos. O princípio da fungibilidade é descendente direto do princípio da instrumentalidade das formas,

16 WAMBIER. Op. Cit. p. 475.

17 DIDIER JR. Op. Cit. p. 371. 
que é mais genérico, e significa que, preenchidas determinadas condições, tanto um meio, quanto outro, podem ser empregados (= podem ser considerados adequados) para se chegar a determinado resultado.

A razão de ser deste princípio é, a toda evidência, de que a parte não sofra prejuízos decorrentes muito comumente da falta de clareza da lei, que se reflete na falta de unanimidade da doutrina e da jurisprudência quanto a qual seria o recurso correto para impugnar tal decisão. Ora, evidentemente, a mesma razão comparece em muitos outros casos em que à parte são oferecidos diversos caminhos (na verdade, basta que sejam dois...) para se chegar a um mesmo lugar ${ }^{18}$.

E reconhece, a festejada doutrinadora, que na atualidade, em especial se se sopesar a economicidade processual e o rigor técnico, razão não existiria para que este rigor se acentuasse à economia, em especial quando pensamos em processo como meio para obtenção de direito.

Porém, o fato é que, se se quiser aproveitar o processo, pode-se lançar mão da teoria da aparência: a sentença apresentava, em primeiro lugar, ser uma sentença, e em segundo lugar, aparentava também ter transitado em julgado. Ademais, como nela se decidiu o mérito, apesar da ausência de pressuposto processual, ofendeu-se a lei (art. 267, IV do (PC), o que deveria ter levado à extinção do processo sem resolução do mérito.

A que tipo de vantagem levaria o rigorismo consistente em se entender que o meio seria inadequado e recomendar-se à parte que intentasse outra ação? Hoje pensamos: nenhuma.

Parece que a tendência é a de que se entenda ser possível a fungibilidade não só dos recursos, propriamente ditos, e como meios que são de

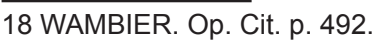


impugnarem decisões judiciais, mas de outros 'meios', hoje evidentemente úteis, como pedidos cautelares, pedidos de antecipação de tutela, meros pedidos, etc. impossível negar-se que, no estado atual do direito, situações existem para as quais pode-se extrair do manejo das regras jurídicas mais de uma solução ou se pode eleger mas de um caminho para chegar a um mesmo lugar ${ }^{19}$.

Desta forma, já decidiu o Tribunal de Justiça de Santa Catarina:

Agravo regimental. Interposição contra decisão que indeferiu a inicial da ação rescisória. Arguida nulidade de citação na ação de usucapião, advinda de fraude e dolo processuais na correta e precisa descrição do imóvel usucapiendo pelos autores, ora agravados. Cabimento de querela nullitatis. Reconsideração do decisum agravado e recebimento da rescisória como ação declaratória, em respeito aos princípios da fungibilidade, da instrumentalidade das formas e da celeridade processual. Providência, no entanto, não exitosa. Impossibilidade de o Tribunal imiscuir-se na jurisdição de órgão inferior, sob pena de supressão de instância. Competência do Juízo singular, prolator da sentença supostamente nula, para o julgamento do feito. Reclamo desprovido. (TJSC, Agravo Regimental em Ação Rescisória n. 2010.063128-4, de Biguaçu, rel. Des. Ronaldo Moritz Martins da Silva, j. 28-07-2011).

Por fim, parece esta também ser o entendimento dos tribunais superiores, em especial do Superior Tribunal de Justiça (REsp 885.477/PR, rel. Min. Francisco Falcão):

AÇÃO RESCISÓRIA. ART. 485, V, DO CPC. VIOLAÇÃO A LITERAL DISPOSITIVO DE LEI. AUSÊNCIA DE REGULARIDADE NA CITAÇÃO DO PROCESSO DE CONHECIMENTO.

19 WAMBIER. Op. Cit. p. 492. 
I - A jurisprudência tem admitido o manejo de Ação Rescisória por violação a literal dispositivo de lei, em face de eventual irregularidade na citação do processo de conhecimento. Precedentes: REsp $n^{\circ}$ 330.293/SC, Rel. Min. RUY ROSADO DE AGUIAR, DJ de 06/05/2002 e REsp no 11.290/ AM, Rel. Min. SÁLVIO DE FIGUEIREDO TEIXEIRA, DJ de 07/06/1993.

II - O art. 485 do CPC, que disciplina as hipóteses de cabimento da Ação Rescisória, não exige o prévio esgotamento dos meios processuais disponíveis para o seu manejo, in casu, a alternativa de fazer inserir a questão em embargos à execução do título judicial atinente à sentença condenatória. Entendimento contrário corresponderia a negar o próprio direito de ação.

III - Recurso Especial provido.

Assim, verifica-se uma precisa consonância na doutrina e na jurisprudência em autorizar o principio da instrumentalidade das formas e sua espécie fungibilidade para fazer o processo como meio de se dar efetividade ao direito pretendido.

\section{CONCLUSÃO}

Concluímos, portanto, que existem diferentes meios de impugnação de decisões judiciais, em especial os próprios recursos, quando se trata de decisão não transitada em julgado, e as ações autônomas de impugnação.

Estas, tratando-se de decisão acobertada pela coisa julgada material, pode ser atacada por ação rescisória, desde que presentes um dos pressupostos autorizadores previstos no art. 485 do CPC, além da atenção ao prazo decadencial de 02 anos.

Tratando-se, contudo, de decisão judicial que seja inexistente, não há que se falar em trânsito em julgado, muito menos em coisa julgada. Fala-se, então, não em rescisão da decisão, mas sim de declaração de inexistência, através de ação própria (querela nullitatis). 
Porém, ressalta-se a importância da ideia de fungibilidade e instrumentalidade das formas no caso de ser uma ação interposta no lugar de outra.

No estagio atual do direito brasileiro, não se pode tão somente ser mantido um formalismo exacerbado pelo modo de se desenvolver o processo. Devemos, porém, ater-nos principalmente ao modo em que este leva à finalidade real, qual seja, a garantia de direito. Há, ainda, que se sopesar os princípios norteadores do processo, quais sejam, a economia processual e a razoável duração do processo hoje elevada a status constitucional.

Assim, verifica-se plenamente possível a fungibilidade das ações impugnativas de decisões judiciais (ação rescisória e ação declaratória de inexistência), sendo tal entendimento abarcado com unicidade pela doutrina e pela jurisprudência nacional.

Abstract: This article focuses on the autonomous impugnation means of judiciary decisions, especially the rescission act and querela nullitatis act. It questions the possibilibity of using the so called fungibility principle among those acts and shows the position of jurisprudence and authors. (MUDAR)

Keywords: Rescission act. Querela nullitatis insanabilis act. Fungibility principle.

\section{REFERÊNCIAS}

DIDIER JR. Fredie. Curso de Direito Processual Civil: meios de impugnação às decisões judiciais e processo nos tribunais. 3 ed. Salvador: JusPodivm, 2007.

MEDINA. José Miguel Garcia. Recursos e Ações Autônomas de Impugnação. 2 ed. São Paulo: RT, 2011.

NERY JUNIOR, Nelson. Princípios do processo na Constituição Federal: processo civil, penal e adminstrativo. 10 ed. São Paulo: RT, 2010. 
WAMBIER, Teresa Arruda Alvim. Nulidades do processo e da sentença. 6 ed. São Paulo: RT, 2007.

WAMBIER, Teresa Arruda Alvim e MEDINA, José Miguel Garcia. O Dogma da Coisa Julgada: Hipóteses de Relativização. São Paulo: Editora Revista dos Tribunais, 2003. 